\title{
Environmental factors affecting the survival of soil dwelling Legionella longbeachae in water
}

\author{
Mia Potočnjak1', Zlatko Magdalenić1, Marija Dijan', Danica Rebić', Ivana Gobin' \\ ${ }^{1}$ Department of Microbiology and Parasitology, Faculty of Medicine, University of Rijeka, Croatia \\ Potočnjak M, Magdalenić Z, Dijan M, Rebić D, Gobin I. Environmental factors affecting the survival of soil dwelling Legionella longbeachae \\ in water. Ann Agric Environ Med. 2016; 23(3): 452-455. doi: 10.5604/12321966.1219186
}

\begin{abstract}
Introduction. Legionella longbeachae, a causative agent of Legionnaire's disease, has often been associated with potting soil and gardening, a feature quite distinct from other Legionella species. The precise transmission mechanism is still unknown, although due to the ecological coherence of the soil and water there is a potential risk of infection by contaminated stagnant water in the garden.

Objective. The aim of the study was to explore the ability of $L$. longbeachae to survive in stagnant tap water usually used for watering in gardens. The influence of different factors (temperature, $\mathrm{pH}$ and $\mathrm{NaCl}$ concentration) on L. longbeachae survival in stagnant tap water was also tested.

Results. The result showed that $L$. longbeachae is viable in stagnant tap water over 100 days at $4{ }^{\circ} \mathrm{C}$ and $25^{\circ} \mathrm{C}$. The survival of L. longbeachae exposed to different $\mathrm{pH}$ and $\mathrm{NaCl}$ concentration suggests resistance to low $\mathrm{pH}$ values ( $\mathrm{pH} 2$ and $\mathrm{pH} 5)$ and all tested $\mathrm{NaCl}$ concentrations at temperatures lower than $25^{\circ} \mathrm{C}$. The ability of $\mathrm{L}$. longbeachae to persist in stagnant tap water should be taken seriously in the risk assessments as a possible hidden reservoir of infection.
\end{abstract}

\section{Key words}

Legionella, survival, stagnant tap water, temperature

\section{INTRODUCTION}

Legionella longbeachae is a significant human pathogen that causes legionellosis in Australia and New Zealand, and is an emerging pathogen worldwide [1, 2, 3, 4]. Two clinical manifestations of legionellosis are Pontiac fever and Legionnaires' disease; the latter presents a far more serious health threat in a form of pneumonia that can be fatal [5]. Recent studies have reported an increased number of infections in Europe $[5,6,7]$. It is important to notice that the diagnosis of infection with Legionella spp. other than Legionella pneumophila has been a persistent challenge. L. longbeachae would not be distinguished from L. pneumophila with the routine Legionella urinary antigen tests; therefore, infections caused by this species of Legionella occur are under- detected [8]. Despite causing a clinically indistinguishable infection, they have distinct environmental niches: L. pneumophila is an aquatic organism, found in both natural and human-made aquatic environments, and L. longbeachae is predominantly found in soil environments, with most human infections associated with contaminated potting soil, particularly with dripping hanging pots and poor garden hygiene $[6,9]$. The main route of transmission of Legionnaires' disease is the inhalation or aspiration of water aerosols contaminated with L. pneumophila. For infection linked to gardening and compost use, it is still questionable whether L. longbeachae is present in the dust or aerosol.

Although belonging to the same genus and sharing some basic common characteristics, different studies have shown significant differences in the intracellular life cycle in amoeba and human cells, as well as in the genome of L. longbeachae and L. pneumophila $[7,10]$. L. longbeachae also

Address for correspondence: IvanaGobin, Faculty of Medicine, Department of Microbiology and Parasitology, University of Rijeka, Brace Branchetta 20, 51000 Rijeka, Croatia

E-mail: ivana.gobin@uniri.hr

Received: 14 September 2015; accepted: 09 March 2016 shows distinction in its virulence factors which might help its survival in the potting soil environment - production of a capsule, the chemotaxis system and cellulolytic enzymes [10].

The water environment presents a natural habitat for most Legionella species where these bacteria live in a biofilm and survive and multiply within free-living amoebae [11]. The risk of infection caused by the L. pneumophila, has been well investigated throughout the years [12]. Factors affecting the survival of L. pneumophila in water have been well explored, and the optimal range of $\mathrm{pH}$ for survival is between $6.0-8.0$ and temperatures between $25^{\circ} \mathrm{C}$ and $42^{\circ} \mathrm{C}$ [13]. Also, L. pneumophila showed resistance to chlorine, which is routinely used to disinfect water [14]. Previously, we have shown that both Legionella species, L. pneumophila and L. longbeachae, survive for more than 30 days in rainwater samples [15]. Taking this under consideration, we now explore the environmental conditions in stagnant tap water that might pose a potential reservoir of L. longbeachae infection, shedding new light on this under- investigated Legionella strain.

\section{MATERIALS AND METHOD}

Bacterial strain. In this the study, L. longbeachae serogroup I (A5H5 strain), clinical isolate from Australia, kindly provided by Elizabeth L. Hartland, Department of Microbiology and Immunology, University of Melbourne, Australia was used. Bacteria were stored at $-80^{\circ} \mathrm{C}$ in glycerol broth (Biolife, Italy) and were cultured by standard procedures on buffered charcoal yeast extract agar (BCYE agar pH 6.9) (Oxoide, England), supplemented with sterile ferric acid and L-cystein, at a temperature of $35 \pm 2{ }^{\circ} \mathrm{C}$.

Stagnant tap water. In all experiments, tap water from the public water supply of the city of Rijeka, Croatia, was used. The salinity, $\mathrm{pH}$ values and conductivities of tap water used in 
this study in the test period was: salinity amounted to $0, \mathrm{pH}$ ranged from 7.5-8.0, and conductivity from $216-300 \mu \mathrm{S} / \mathrm{cm}$. According to these characteristics, the water was medium hard. The tap water was sterilized by autoclaving and kept in a glass bottle at room temperature for 2 days for the evaporation of free residual chlorine prior to testing.

Inoculum. L. longbeachae was cultured on BCYE for 3 days at $35 \pm 2{ }^{\circ} \mathrm{C}$ and then subcultured in AYE broth at $35 \pm 2{ }^{\circ} \mathrm{C}$ for a further 2 days. Bacteria were harvested by centrifugation at 5,000 g for $10 \mathrm{~min}$, the pellet was washed twice in a sterile stagnant tap water and bacterial suspension, adjusted to an OD600 $\mathrm{nm}$ of $1\left(1 \times 10^{9} \mathrm{CFU} / \mathrm{ml}\right)$. Further dilution was prepared and suspensions of approximately $10^{6} \mathrm{CFU} / \mathrm{ml}$ and $10^{8} \mathrm{CFU} / \mathrm{ml}$ in $10 \mathrm{~mL}$ stagnant tap water were used in survival studies. The viable bacterial counts were confirmed retrospectively by cultivating serial ten-fold dilution on $\mathrm{BCYE}$ agar plates. All the experiments were performed in triplicate.

Temperatures. The effects of different temperatures $\left(4^{\circ} \mathrm{C}\right.$, $25^{\circ} \mathrm{C}, 37^{\circ} \mathrm{C}$ and $42^{\circ} \mathrm{C}$ ) on the survival of L. longbeachae in stagnant tap water were tested [16].

pH. Four different $\mathrm{pH}$ values were tested: $\mathrm{pH} 2, \mathrm{pH} 5, \mathrm{pH} 7$ and $\mathrm{pH} 8$. Each value was tested at $25^{\circ} \mathrm{C}$ and $37^{\circ} \mathrm{C}$ [13].

$\mathrm{NaCl}$ solutions. Five different salt solutions were used to study the salt tolerance of $L$. longbeachae. The following concentrations were tested: $0.8 \%, 1 \%, 2 \%$, and $3 \%(\mathrm{w} / \mathrm{v}) \mathrm{NaCl}$. Sodium chloride was dissolved in distilled water, autoclaved, and distributed in plastic test tubes (TPP, Switzerland). Sterile, distilled water was used as a control. Each concentration was tested at 25 and $37^{\circ} \mathrm{C}(6)$.

Survival studies. Viable L. longbeachae counts were determined by cultivating the samples immediately after inoculation and at different time points up to 50 or 100 days. For each time point, 3 plastic test tubes (TPP, Switzerland) were inoculated in parallel. Cultures were vortexed and the number of viable bacteria in the samples was determined by enumeration of the bacteria on BCYEa-agar.

\section{RESULTS AND DISCUSSION}

A water environment presents a unique challenge for bacterial survival, mainly because of the lack of nutrients. Recently, the global incidence of reported L. longbeachae infections increased, but the factors explaining this emergence of infections are still unknown. The major source of human infection is considered to be commercial potting mixes and other decomposing materials, such as bark and sawdust [4, $6,17]$. L. longbeachae is not often detected in water samples and man-made water systems [4]. The assumption is that the primary transmission mode of this microorganism is inhalation of dust or water aerosol created during watering from contaminated compost or soil. Steele et al. suggested that L. longbeachae leaches out of potting mix after watering, and may be present in any aerosols formed during the watering process, which could be inhaled by the gardener [6]. It is very common for people to collect rain and tap water to use for watering their gardens; however, this creates aerosols which could present potential health risks. Although laboratory microcosms are not exact replicates for condition in nature, they can provide baseline ecological information. Therefore, we explored how different environmental conditions affect the survival of L. longbeachae in stagnant tap water.

L. longbeachae is viable in stagnant tap water for over 100 days. We have shown that stagnant tap water is a suitable medium for the survival of L. longbeachae, and after analyzing all tested conditions the survival of bacteria was longer when the inoculum was higher. The presented results show that higher temperature, as well as a lower number of bacteria, had a negative impact on the survival of L. longbeachae in stagnant tap water (Fig. 1). After inoculating $10^{6} \mathrm{CFU} / \mathrm{ml}$ bacteria in the tap water a loss of cultivability on temperatures $42^{\circ} \mathrm{C}, 37^{\circ} \mathrm{C}$ and $25^{\circ} \mathrm{C}$, at day 5, 15 and 90, were detected, respectively. These results are consistent with the results of Arago-Cerveroet al. who recently showed the sensitivity of $L$. longbeachae to thermal treatment in tap water at temperatures above $50^{\circ} \mathrm{C}$ [14]. In the same study, L. longbeachae was extremely sensitive to chlorine concentrations of $0.2 \mathrm{mg} / \mathrm{ml}$ and $0.5 \mathrm{mg} / \mathrm{ml}$. In the presented experiments we used stagnant tap water in which the chlorine level was reduced during the testing period which led to increased bacterial survival. This model mimics the conditions during gardening. At $4{ }^{\circ} \mathrm{C}$ the number of bacteria declined for 2 log units by the end of the experiments $\left(100^{\text {th }}\right.$ day after inoculation). When higher inoculums was used, L. longbeachae was cultivable at $4^{\circ} \mathrm{C}$ and $25^{\circ} \mathrm{C}$ during the whole experiment period, while at $37^{\circ} \mathrm{C}$ and $42^{\circ} \mathrm{C}$, for 25 and 5 days, respectively.

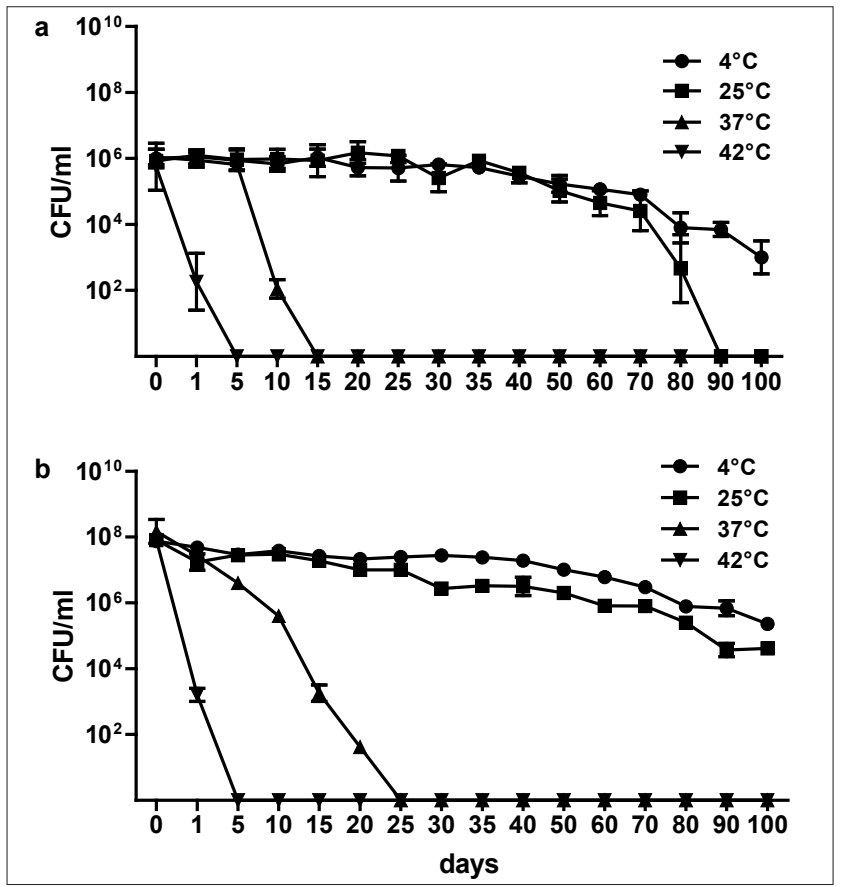

Figure 1. Effect of inoculum sizes $10^{6} \mathrm{CFU} / \mathrm{mL}$ (a) and $10^{8} \mathrm{CFU} / \mathrm{mL}$ (b) and temperature on survival of $L$. longbeachae in tap water. Plate counts were performed at various time points to determine the number of viable cells

Diverse temperature optimum between two Legionella species. The ideal temperature range for L. pneumophila propagation is between $25^{\circ} \mathrm{C}-42{ }^{\circ} \mathrm{C}$ [18], whereas L. longbeachae favours a lower temperature range of between $4^{\circ} \mathrm{C}-25^{\circ} \mathrm{C}$. Also, L. longbeachae is more sensitive to $\mathrm{pH}$ under 

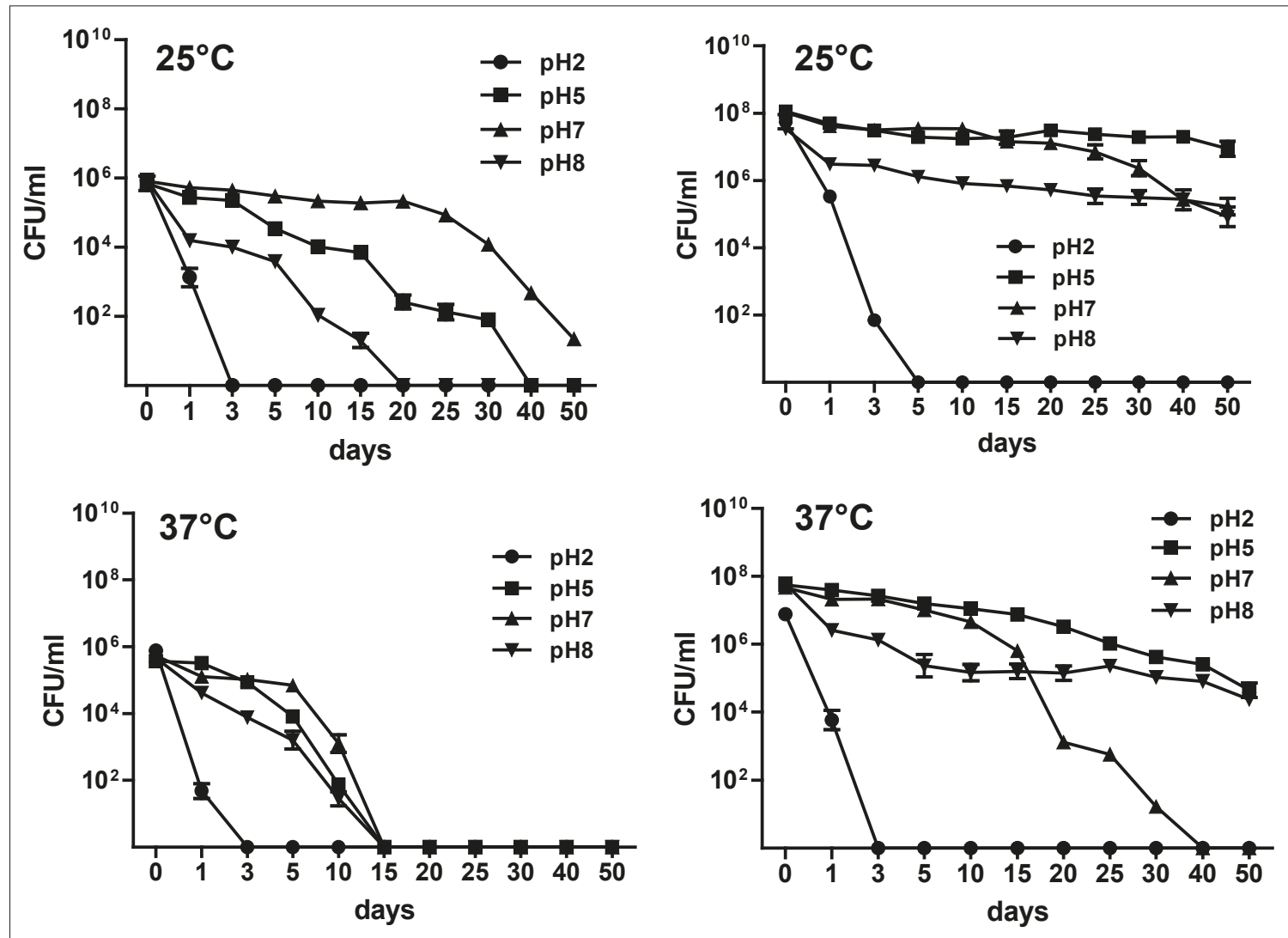

Figure 2. Effect of inoculum sizes $\left(10^{6} \mathrm{CFU} / \mathrm{mL}\right.$ (left) and $10^{8} \mathrm{CFU} / \mathrm{mL}$ (right)), $\mathrm{pH}\left(\mathrm{pH} 2, \mathrm{pH} 5, \mathrm{pH} 7\right.$ and $\mathrm{pH} 8$ ) and temperature $\left(25^{\circ} \mathrm{C}\right.$ and $\left.37^{\circ} \mathrm{C}\right)$ on the survival of $L$. longbeachae in tap water. Plate counts were performed at various time points to determine the number of viable cells

incubation at higher temperature of $37^{\circ} \mathrm{C}$, and loss of cultivability was detected after exposure to $\mathrm{pH} 2$ and $\mathrm{pH} 7$ after 3 and 40 days, respectively (Fig. 2). In the current study, the presence of viable but non-cultivable (VBNC) were not investigated.

Resistance of $L$. longbeachae to extremely low pH. A larger inoculum size $\left(10^{8} \mathrm{CFU} / \mathrm{ml}\right)$, and incubation at $25^{\circ} \mathrm{C}$ extended survival time when exposed to altered $\mathrm{pH}$ values; with the exception of $\mathrm{pH} 2$ when bacteria were cultivable after 50 days (Fig. 2). Katz and Hammel demonstrated that L. pneumophila was cultivable for 1 month in tap water varying in $\mathrm{pH}$ from 4.0-8.0 [19]. With extremely low $\mathrm{pH} 2$ where L. pneumophila is rapidly killed and most of bacteria survived for only a few hours, L. longbeachae survived up to 3 days, suggesting the resistance of this bacteria to low $\mathrm{pH}$ [18].

Long survival in an unfavourable water environment. The survival of $L$. longbeachae in distilled water, as well as in distilled water with different $\mathrm{NaCl}$ concentrations was examined. Significantly better survival was detected at $25^{\circ} \mathrm{C}$ where bacteria were cultivable more than 50 days. The present results are in accordance with earlier studies showing that a small amount of $\mathrm{NaCl}$ enhanced the survival of Legionella at lower temperatures $[16,20]$. L. longbeachae were cultivable for 50 days in pure sterile distilled water (Fig. 3). One explanation is a recent discovery which suggests that this bacterium possesses a capsule which enables its longer survival in unfavorable environmental conditions [10]. However, we wish to point out that the structure and function of a L. longbeachae capsule has not yet been characterized, nor whether the capsule affects the survival of this bacterium in different environmental conditions. Further research is necessary.

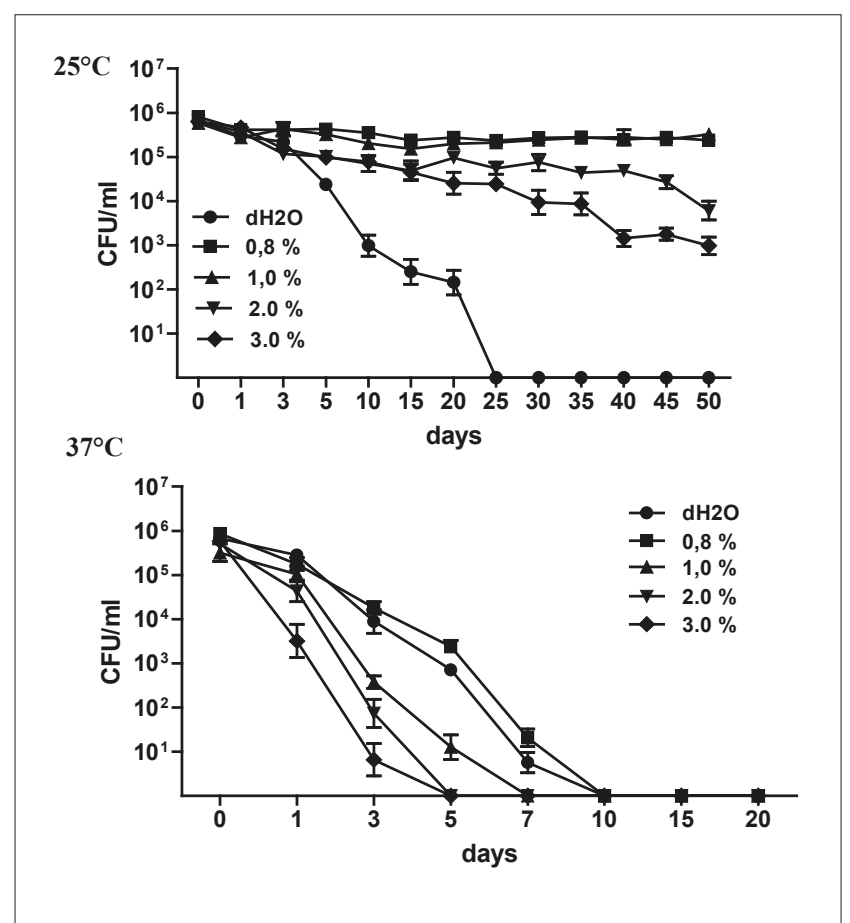

Figure 3. Effect of incubation temperature $\left(25^{\circ} \mathrm{C}\right.$ and $\left.37^{\circ} \mathrm{C}\right)$ and different concentrations of $\mathrm{NaCl}$ on the survival of Legionella longbeachae in distilled water. Plate counts were performed at various time points to determine the number of viable cells 


\section{CONCLUSION}

The soil dwelling Legionella is able to survive in stagnant tap water under lower temperatures for a long period of time and is relatively resistant to changes of $\mathrm{pH}$ and the concentrations of $\mathrm{NaCl}$. These conditions are possible to find in stagnant tap water in gardens, making it a potential reservoir of L. longbeachae infection. The presented study contributes to the incomplete knowledge about the impact of fundamental environmental factors on the survival of $L$. longbeachae in a water environment, but further research of this bacterium is required, e.g. its natural habitat, propagation abilities, and life cycles.

\section{REFERENCES}

1. Koide M, Arakaki N, Saito A. Distribution of Legionella longbeachae and other legionellae in Japanese potting soils. J Infect Chemother. 2001; 7(4): 224-7.

2. McKinney RM, Porschen RK, Edelstein PH, Bissett ML, Harris PP, Bondell SP, et al. Legionella longbeachae species nova, another etiologic agent of human pneumonia. Ann Intern Med. 1981; 94(6): 739-43.

3. Montanaro-Punzengruber JC, Hicks L, Meyer W, Gilbert GL. Australian isolates of Legionella longbeachae are not a clonal population. J Clin Microbiol. 1999; 37(10): 3249-54.

4. O’Connor BA, Carman J, Eckert K, Tucker G, Givney R, Cameron $\mathrm{S}$. Does using potting mix make you sick? Results from a Legionella longbeachae case-control study in South Australia. Epidemiol Infect. 2007; 135(1): 34-9.

5. Currie SL, Beattie TK. Compost and Legionella longbeachae: an emerging infection? Perspect Public Health. 2015;135(6):309-15.

6. Steele TW, Lanser J, Sangster N. Isolation of Legionella longbeachae serogroup 1 from potting mixes. Appl Environ Microbiol. 1990; 56(1): 49-53.

7. Asare R, Santic M, Gobin I, Doric M, Suttles J, Graham JE, et al. Genetic susceptibility and caspase activation in mouse and human macrophages are distinct for Legionella longbeachae and L. pneumophila. Infect Immun. 2007; 75(4): 1933-45.

8. Gobin I, Newton PR, Hartland EL, Newton HJ. Infections caused by nonpneumophila species of Legionella. Rev Med Microbiol. 2009; 20(1): 1-11.

9. Cramp GJ, Harte D, Douglas NM, Graham F, Schousboe M, Sykes K. An outbreak of Pontiac fever due to Legionella longbeachae serogroup 2 found in potting mix in a horticultural nursery in New Zealand. Epidemiol Infect. 2010; 138(1): 15-20.

10. Cazalet C, Gomez-Valero L, Rusniok C, Lomma M, Dervins-Ravault $\mathrm{D}$, Newton HJ, et al. Analysis of the Legionella longbeachae genome and transcriptome uncovers unique strategies to cause Legionnaires' disease. PLoS Genet. 2010; 6(2): e1000851.

11. Molofsky AB, Swanson MS. Differentiate to thrive: lessons from the Legionella pneumophila life cycle. Mol Microbiol. 2004; 53(1): 29-40.

12. Fields BS, Benson RF, Besser RE. Legionella and Legionnaires' disease: 25 years of investigation. Clin Microbiol Rev. 2002; 15(3): 506-26.

13. Wadowsky RM, Wolford R, McNamara AM, Yee RB. Effect of temperature, $\mathrm{pH}$, and oxygen level on the multiplication of naturally occurring Legionella pneumophila in potable water. Appl Environ Microbiol. 1985; 49(5): 1197-205.

14. Cervero-Aragó S, Rodríguez-Martínez S, Puertas-Bennasar A. Effect of Common Drinking Water Disinfectants, Chlorine and Heat, on Free Legionella and Amoebae-Associated Legionella. PLoS One. 2015; 1-18.

15. Potočnjak M, Široka M, Rebić D, Gobin I. The survival of Legionella in rainwater. Int J Sanit Eng Res. 2012; 6(1): 31-6.

16. Heller R, Höller C, Süssmuth R, Gundermann KO. Effect of salt concentration and temperature on survival of Legionella pneumophila. Lett Appl Microbiol. 1998; 26(1): 64-8.

17. Whiley H, Bentham R. Legionella longbeachae and legionellosis. Emerg Infect Dis. 2011; 17(4): 579-83.

18. Ohno A, Kato N, Yamada K, Yamaguchi K. Factors influencing survival of Legionella pneumophila serotype 1 in hot spring water and tap water. Appl Environ Microbiol. 2003 May; 69(5): 2540-7.

19. Katz SM, Hammel JM. The effect of drying, heat, and $\mathrm{pH}$ on the survival of Legionella pneumophila. Ann Clin Lab Sci. 1987; Jan;17(3): 150-6.

20. States SJ, Conley LF, Kuchta JM, Oleck BM, Lipovich MJ, Wolford RS, et al. Survival and multiplication of Legionella pneumophila in municipal drinking water systems. Appl Environ Microbiol. 1987; 53(5): 979-86. 